NBER WORKING PAPER SERIES

COMMODITY PRICES AND INELATION: EVIDENCE FROM SEVEN LARGE INDUSTRIAL COUNTRIES

James M. Boughton

William H. Branson

Alphecca Muttardy

Working Paper No. 3158

NATIONAL BUREAU OF ECONOMIC RESEARCH

1050 Massachusetts Avenue

Cambridge, MA 02138

November 1989

We would like to thank Richard Bafllie, Chris Gilbert, Tim Jenkinson, Anne McGuirk, and David Vines for a number of helpful comments and suggestions; and Ximena Cheetham and Tom Walter for extensive research assistance. The study benefitted from comments in seminars at the IMF, CEPR in London, the Banks of Italy and Spain, and the IIES in Stockholm. This paper is part of NBER's research programs in Economic Fluctuations and International Studies. Any opinions expressed are those of the authors not those of the National Bureau of Economic Research. 
NBER Working Paper \#3158

November 1989

\title{
COMMODITY PRICES AND INFLATION: EVIDENCE FROM SEVEN LARGE INDUSTRIAL COUNTRIES
}

\begin{abstract}
Th1s paper examines the relationships between movements in primary commodity prices and changes in inflation in the large Industrial countries. It begins by developing a two-country model in order to examine the theoretical effects of monetary, fiscal, and supply-side disturbances on commodity and manufactures prices and on exchange rates. It is shown that if monetary shocks dominate, then commodity prices should lead general price movements, and the level of commodity prices should be correlated with the general inflation rate. Non-monetary shocks generally weaken these relationships, but such disturbances may cancel out for broad indexes covering a wide range of commodities.

Country-specific commodity price indexes are developed for the major industrial countries. The weights assigned to different commodities vary substantially across countries. Nonetheless, when the indexes are expressed in a common currency, they tend to be highly correlated over time, except when sharp movements occur in certain commodity prices. The major source of contrast across countries in the behavior of the indexes derives from exchange rate movements.

Several empirical tests broadly support the conclusions of the theoretical model, with relatively few differences across countries. Three main tendencies may be cited. First, low inflation in industrial countries has tended to be associated with low levels of commodity prices, and conversely; commodity-price levels are cointegrated with consumer-price inflation rates. Second, there has been some tendency for movements in commodity prices to precede changes in general inflation rates by a few months, although it is not clear whether this tendency is strong enough to be a rellable aid in forecasting the rate of inflation. Third, there is a strong and fairly reliable tendency for turning points in general inflation rates. Commodity prices thus appear to contribute to predictions of turning points in inflation, predictions of inflation rates but more strongly to predictions of turning points in inflation.
\end{abstract}

James $M$. Boughton Alphecca Muttardy Research Department IMF Washington, DC 20431 (202)623-7477
William H. Branson Woodrow Wilson School Princeton University Princeton, NJ 08544 (609) $258-4828$ 


\section{Introduction and Summary}

Considerable interest has arisen regarding the relationship between commodity prices and broader measures of inflationary pressures. An earlier paper (Boughton and Branson, 1988) argued that a conventional trade-weighted index of world commodity prices contains useful information about future changes in the average inflation rate in large industrial countries. This paper extends that research in two directions: (1) by developing a theoretical open-economy model in which countries differ in the role that is played by commodity prices; and (2) by deriving commodity price indexes that are specific to each country and testing the relationships between those indexes and inflation in the countries concerned.

Section II describes the theoretical model and suggests a number of hypotheses to be tested. A conclusion of this section is that commodity price movements should lead general price movements as long as disturbances are predominantly monetary. If commodity prices jump in response to such disturbances, while other prices respond more gradually, . then the level of commodity prices should be positively correlated (and cointegrated) with the rate of inflation in manufactures prices. These conclusions should apply more to broad commodity price indexes, on which the effects of supply shocks to specific commodities are relatively weak, than to narrow indexes. Even so, unaccommodated fiscal policies and other general real disturbances could create substantial noise in the relationships between general price inflation and movements in broad commodity price indexes.

The new commodity price indexes are presented and discussed in Section III. The distribution of weights among commodities varies 
markedly across countries, but as long as the indexes are denominated in the same currency the variation in their intertemporal movements is Iimited. The major source of contrast in the behavior of the individualcountry indexes derives from exchange rate movements.

Empirical tests of the relationships between the commodity price indexes and general inflation rates are the subject of sections IV and $V$. Section IV presents some cointegration tests that suggest the possibility that the level of commodity prices may be cointegrated with the rate of inflation in consumer prices; that is, low inflation in industrial countries appears to be associated with low levels of commodity prices, and conversely. Various single-equation tests of predictive power indicate that there is some tendency for movements in commodity prices to precede consumer price changes and to contribute to inflation predictions; this tendency, however, is not observed in all countries, nor in all time periods. Commodity price indexes have a stronger predictive relationship with turning points in consumer price inflation than with the level of the inflation rate.

Section $V$ discusses evidence regarding the relationship between commodity prices and output deflators. No evidence is found to support the hypothesis that the linkages with output deflators are stronger in countries that have a relatively large share of output attributed to primary commodities. In general, commodity prices contribute to predictions of output deflators with slightly less power than in the case of consumer prices. The paper concludes with a brief discussion of some econometric model simulations that broadly confirm the major predictions of the theoretical model and the single-equation tests. 
II. A Two-Country Model of Commodity Prices, Exchange Rates, and Inflation

This section presents a dynamic model of commodity and industrial prices in a framework of two goods and two countries. The goods are commodities and manufactures, with their prices determined in a world market in a common currency, the Group Currency Unit (GCU). 1/ The two countries have a floating exchange rate and different structures of production. The exchange rate of each against the GCU translates the prices of the two goods into the home currencies. The weights of the two goods in production and consumption in each country then determine the movements of the GNP deflator and the CPI, respectively. The model has two levels. The world market (subsection 1) determines the relative goods prices, while a relative monetary model (subsection 2) determines exchange rates. The two together give home-currency prices.

1. World model of commodities and manufactures prices

This subsection discusses a dynamic model of the interaction of commodity and manufactures prices at the level of the world market. Commodity prices are determined in flexible world markets with forwardlooking expectations. Manufactures prices are set by sellers and adjust gradually. The model is essentially the same as the one presented in Boughton and Branson (1988), interpreted now as a world model in GCU. Equilibrium in the world money market is described in the standard form of equation ( 1 ):

1 Conceptually, the GCU is an implicit weighted average of the two currencies. It is defined for the general multi-country case in Boughton and Branson (1988). 
(1) $\mathrm{m}-\alpha_{\mathrm{Pm}_{\mathrm{m}}}-(1-\alpha) \mathrm{P}_{\mathrm{c}}=\phi \mathrm{y}-\lambda 1$.

Here $m, P_{m}, P_{c}$, and $y$ are the logarithms of nominal world money, the price of manufactures, the price of commodities, and world real output, all expressed in GCU; $i$ is the average world nominal short-term interest rate; and $\alpha$ is the share of manufactures in world output, and in the world CPI. Commodity price inflation and the interest rate are related by the arbitrage condition:

(2) $i-\dot{\mathrm{p}}_{c}+\mathrm{b}$, where $b$ is the real return to holding commodities for final use, net of storage costs, and $\dot{\mathrm{p}}_{\mathrm{c}}$ is the expected rate of change of the commodity price. Substitution of equation (2) into (1) ylelds the first dynamic equation:

(3) m- $\alpha \mathrm{pm}_{\mathrm{m}}-(1-\alpha) \mathrm{p}_{\mathrm{c}}=\phi \mathrm{y}-\lambda\left(\dot{\mathrm{p}}_{\mathrm{c}}+\mathrm{b}\right)$.

The downward-sloping locus of points where $\dot{\mathrm{P}}_{c}-0$ is shown in Figure 1; its slope is $-(1-\alpha) / \alpha$.

For a point above the $\dot{\mathrm{P}}_{\mathrm{c}}=0$ line to be consistent with money market equilibrium, $P_{c}$ must be expected to rise. This is because above the line, $P_{c}$ is higher, and real balances are lower, than on $1 t$, so the interest rate must exceed $b$, and $P_{c}$ must therefore be expected to rise. If expectations exhibit perfect foresight, $P_{c}$ must actually be rising above the line. These dynamics of the GCU commodity price are summarized by the horizontal arrows in Figure 1. 
- $4 a-$

FinE I
COMMODITY AND MANUFACTURES PRICES:

WORLD EQUILIBRIUM AND DYNAMICS

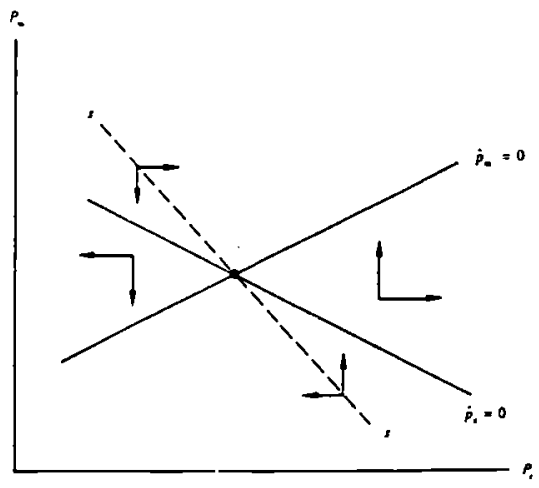

Figure s

WORLD MARKET RESPONSE TO REAL DISTURBANCE ALTERING RELATIVE PRICES

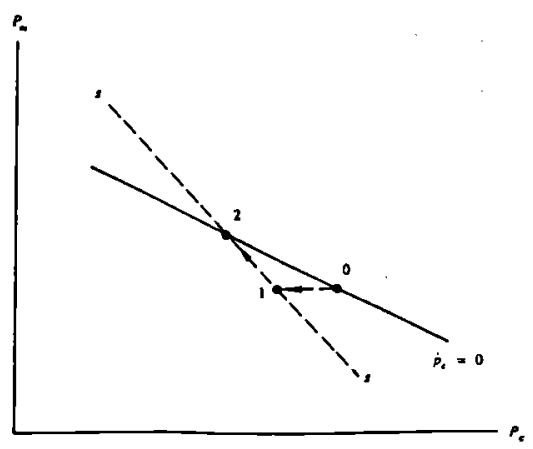

Figure 2

WORLD MARKET RESPONSE TO UNANTICIPATED MONETARY EXPANSION

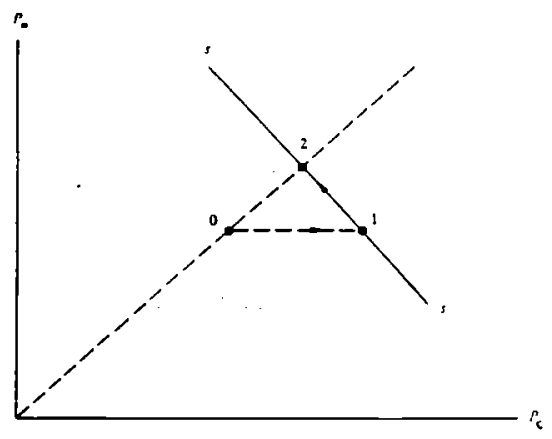

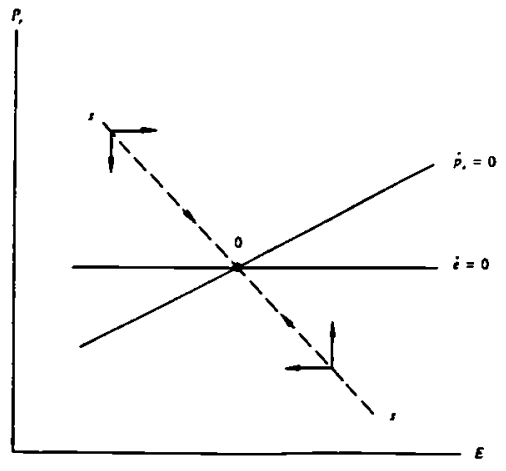


The supply of real industrial output $y_{m}$ is assumed to be constant. Demand is assumed to be an increasing function of the price of commodities relative to manufactures, $P_{c} / P_{m}$, and a decreasing function of the real interest rate in terms of manufactures. Thus demand is given by

(4) $d-\delta\left(\mathrm{P}_{c}-\mathrm{P}_{\mathrm{m}}\right)-\sigma\left(\mathbf{i}-\dot{\mathrm{P}}_{\mathrm{m}}\right)+\mathrm{g}$,

where $g$ is the logarithm of exogenous expenditure, which can represent aggregate world fiscal policy. We assume that a fiscal expansion increases the relative demand for industrial goods.

The price of manufactures is assumed to adjust gradually to eliminate excess demand:

(5) $\dot{\mathrm{p}}_{\mathrm{m}}=\pi\left[\delta\left(\mathrm{p}_{\mathrm{c}}-\mathrm{p}_{\mathrm{m}}\right)-\sigma\left(\mathbf{i}-\dot{\mathrm{p}}_{\mathrm{m}}\right)+\mathrm{g}-\mathrm{y}_{\mathrm{m}}\right]$.

The terms in $p_{m}$ can be consolidated to yield the second dynamic equation:

(6) $\dot{\mathrm{p}}_{\mathrm{m}}=\eta\left[\delta\left(\mathrm{p}_{\mathrm{c}}-\mathrm{p}_{\mathrm{m}}\right)-\sigma i+\mathrm{g}-\mathrm{y}_{\mathrm{m}}\right]$,

where $\eta=\pi /(1-\pi \sigma)$. This term must be positive if a positive shock to excess demand is to raise the price of manufactures.

The positively sloped $\dot{\mathrm{p}}_{\mathrm{m}^{-}}-0$ line in Figure 1 is the locus of points along which excess demand for manufactured goods is zero, given the value of the world money stock, which influences the world nominal interest rate $i$. The slope is less than unity because an increase in the price level raises the interest rate and reduces the demand for manufactured output. At points above the $\dot{\mathrm{p}}_{\mathrm{m}}=0$ line, there is an excess world supply of manufactured goods, and their CGU price is falling, assuming $\eta>0$. Below the line, there is excess demand and the price is rising. The 
dynamics of adjustment of the GCU manufactured price are summarized by the vertical arrows in Figure 1.

The intersection of the two equilibrium lines in Figure 1 gives the equilibrium pair of GCU world prices for given world money stock, fiscal policy, and real supply conditions. $1 /$ Dynamic adjustment to the equilibrium proceeds along the stable saddle path ss. This path has two essential properties: It leads to the equilibrium (technically, satisfies the transversality conditions implicit in the model), and along it the expected rate of change of the commodity price is realized. All other paths with expectations realized from period to period explode away from the equilibrium; they are speculative bubbles. The assumption that the market seeks out the stable ss path following a disturbance is the same as assuming that speculative bubbles are unsustainable.

The model of Figure 1 can be used to show the potential usefulness of movements of commodity prices as an indicator of future inflation. Consider an unanticipated increase in the world money supply, originating in either country. In the long run, both prices would increase proportionately in GCU. Thus in Figure 1 both the $\dot{\mathrm{p}}_{c}=0$ and the $\dot{\mathrm{p}}_{\mathrm{m}}=0$ lines shift out, so that the long-run equilibrium moves out proportionately. This is shown as the movement from point 0 to point 2 in Figure 2, which also shows the new ss path into the new equilibrium. The commodity price can adjust instantaneously to reflect the expected inflation, while the manu-

1) There is a difficulty in interpreting the model's equilibrium as a steady-state position, because interest rate data tend not to be stationary. Specifically, while money stocks, GNP, and GNP delators are generally integrated of degree zero, interest rates may be integrated of degree one. 
factures price can adjust only over time. Thus in Figure 2, the flexible commodity price jumps onto the new ss path at point 1 , and then the two prices adjust gradually along the ss path to point 2 . In response to an unanticipated monetary shock, commodity prices jump and overshoot, and lead the subsequent inflation in industrial prices.

In response to repeated monetary shocks, jumps in the level of commodity prices would lead changes in the rate of inflation of industrial prices. This should produce a positive correlation between the level of world GCU commodity prices and the subsequent rate of inflation of manufactures prices if repeated monetary disturbances are empirically important. Cointegration of the level of commodity prices and the rate of inflation in consumer prices is not rejected in the statistical tests in Section IV (Table 4), below.

The effects of an unanticipated real disturbance that changes the equilibrium relative price $P_{m} / P_{c}$ are shown in Figure 3 . There we assume that the disturbance increases the equilibrium relative price. This could be due to a supply shock that increases commodity supply relative to the supply of manufactures; for example, an innovation in commodity production. It could also result from a shift in demand toward manufactures; for example, a fiscal expansion. This disturbance shifts the $\dot{\mathrm{P}}_{\mathrm{m}}-0$ line up along the $\dot{\mathrm{P}}_{c}=0$ line to a new long-run equilibrium at point 2, which lies on a steeper ray from the origin that characterizes a higher $\mathrm{Pm} / \mathrm{Pc}$ ratio. If there is no monetary accommodation to the disturbance, the $\dot{\mathrm{P}}_{\mathrm{c}}=0$ line does not move. The result is that the commodity price jumps down onto the new ss path at point 1 , and then continues to fall, while the industrial price rises to the new equilibrium at point 2 . The com- 
modity price undershoots in response to a real disturbance. It moves before the industrial price, but in the opposite direction. With no monetary accommodation, for the $P_{m} / P_{c}$ ratio to rise, $P_{m}$ must increase and $P_{c}$ must fall.

It could appear from this analysis that commodity prices would not be a useful indicator of future inflation in the presence of unaccommodated real disturbances. In fact, in this model, as long as the real disturbance is not accommodated, there is no general inflation. As one price rises, the other falls to keep the weighted CPI in GCU constant. Thus a stochastic serles of aggregate real shocks would produce stochastic behavior of the commodity price with no general inflation. If in empirical implementation we use an index of a variety of commodity prices, real supply shocks would come from differing sources, depending on the commodity. To the extent that these are independent, offsetting negative and positive disturbances at the individual commodity level would minimize the contribution of supply shocks to the variance of the index. Thus the path of the index would be dominated by monetary disturbances, with real disturbances producing noise around that path. The contribution of real supply shocks to the variance of the index would be minimized to the extent that they are uncorrelated. This would improve the usefulness of the Index as an inflation indicator.

At this point we can summarize the results from the world model of commodity and manufactures prices in GCU. Monetary disturbances lead to jumps in the commodity price index, followed by gradual movement in the manufactures price in the same direction. The long run movement of both prices is proportional to the monetary disturbance. Thus a series of 
positive monetary shocks would produce a series of jumps in the level of commodity prices and smoother inflation in manufactures prices, with a common trend to both. Real disturbances yield jumps in the commodity price, followed by gradual movement of the manufactures price in the opposite direction. If the real disturbances are not accomodated by monetary policy, they have no long-run effect on the CPI, but they produce noise in the commodity price series. If the real disturbances have in them a trend that raises the relative price of manufactures, they will generate noise around that trend.

\section{Relative mode1 of prices and exchange rates}

The world model gives us the movements of commodity and manufactures prices in GCU, as functions of world monetary and real disturbances. To translate these into domestic price indexes in individual countries, we can use a model of the exchange rate and relative price levels between two countries. This will give us the relative effects of disturbances, depending on the country of their source. The relative effects can then be combined with the world effects in GCU to obtain the results for CPIs and GDP deflators in home currencies. The relative model is an applica. tion of Aoki's (1981) average and difference method to the Dornbusch (1976) model of prices and the exchange rate.

We begin by defining relative variables between two "representative" countries as the differences between the logarithms of the variables for the domestic GNP deflators, money stocks, GNPs, and fiscal variables; and the arithmetic differences for interest rates, with each relative variable being the standard mnenonic with a subscript " $r$ ". Thus for relative 
prices, we have

$$
P_{r}=\ln P-\ln P^{*},
$$

where $P$ and $P^{*}$ are the home and foreign GNP deflators, respectively. Relative money stocks $\left(m_{r}\right)$, real GNP $\left(y_{r}\right)$, and fiscal variables $\left(g_{r}\right)$ are similarly defined. Each country's GNP will be a combination of commodity, manufactures, and services output, and its GNP deflator will be the corresponding weighted average. The interest differential, equal to the expected rate of change of the nominal exchange rate, $E$, is

$$
1_{r}-1-i^{*}=\dot{e} \text {. }
$$

In equilibrium with $\dot{e}=0, i_{\text {r }}$ would also be $0.1 /$

The model of relative prices and the exchange rate is specified similarly to the model of manufactures and commodity prices described above in subsection 1 . Here the exchange rate is the forward-looking variable that jump in response to unanticipated disturbances, and the relative GNP deflator adjusts slowly to relative excess demand. The relative equilibrium condition for the money market is

(7) $m_{r}-p_{r}-\phi y_{r}-\lambda i_{r}-\phi y_{r}-\lambda \dot{e}$,

using the uncovered interest parity condition to substitute $\dot{e}$ for $i_{r}$.

1/ A risk premium related to relative stocks of outstanding assets could be added to the interest differential. While that extension might provide additional insights, especially regarding the longer-run effects of fiscal policies, it would complicate the analysis without modifying the qualitative conclusions regarding the model's dynamics. 
We can set $\dot{e}=0$ (or $i_{r}=0$ ) in equation (7) to obtain the $\dot{e}=0$ line in Figure 4 , which shows the relative price $p_{I}$ that would clear the money market for given values of $\mathrm{m}_{\mathrm{r}}$ and $\mathrm{y}_{\mathrm{r}}$. In contrast to the $\dot{\mathrm{p}}_{c}=0$ line in Figure 1 , the $\dot{e}=0$ line here is horizontal. For a point above the $\dot{e}=0$ line to be consistent with money-market equilibrium, $E$ must be rising. This is because $\mathrm{pr}_{r}$ is higher than on the line, so $i_{r}$ must be positive above the line. This would mean that $E$ would be expected to rise (so $\dot{e}$ is positive), and on the assumption of perfect foresight, E would actually rise. This reasoning is exactly the same as that behind the $P_{c}$ dynamics in Figure 1.

Relative demand, $d_{r}$, for the two real GNPs is specified as (8) $\mathrm{d}_{\mathrm{r}}=\delta\left(\mathrm{e}-\mathrm{p}_{\mathrm{r}}\right)-\sigma\left(\dot{i}_{\mathrm{r}}-\dot{\mathrm{p}}_{\mathrm{r}}\right)+\mathrm{g}_{\mathrm{r}}$

As in the earlier model, the relative GNP deflator adjusts gradually to excess demand, so that

(9) $\dot{\mathrm{p}}_{\mathrm{r}}=\pi\left(\mathrm{d}_{\mathrm{r}}-\mathrm{y}_{\mathrm{r}}\right)$.

Substituting (8) into (9) and solving for $\dot{p}_{r}$ yields the second dynamic equation,

(10) $\dot{p}_{r}=\eta\left[\delta\left(e-p_{r}\right)-\sigma i_{r}+g_{r}-y_{r}\right]$

where $\eta=\pi /(1-\pi \sigma)$, which is required to be positive. Setting $\dot{\mathrm{P}}_{\mathrm{r}}=0$ in equation (10) yields the positively sloped $\dot{\mathrm{p}}_{\mathrm{r}}-0$ line in Figure 4, for relative GNP deflator equilibrium. As long as $\eta$ is positive, $\operatorname{Pr}$ adjusts toward the $\dot{\mathrm{p}}_{\mathrm{r}}=0$ 1ine. 
The two equilibrium lines in Figure 4 show the equilibrium relative price, measured in the ratio of the two currencies, and the equilibrium exchange rate at point 0 for given relative money stocks, fiscal positions, and supply conditions. Dynamic adjustment to equilibrium proceeds along the saddle path ss, as in the earller model of Figure 1 . The only analytical difference between Figure 1 and Figure 4 is the slope of the curve representing monetary equilibrium. In both models, the saddle path is negatively sloped, and the flexible price jumps horizontally onto the saddle path following an unanticipated disturbance, while the sticky price adjusts gradually along the saddle path.

The effects of a strictly relative monetary disturbance (an increase in the money supply in the home country and a decrease of the same percent in the foreign country) are shown in Figure 5. There is no change at the world level of subsection 1 , since there is no effect on the world money stock. But in the relative model, the long run equilibrium moves out proportionately to point 2 in Figure 5, with the exchange rate and relative. price both increasing in proportion to the change in the relative money supply. The home price level rises and the foreign price level declines . The home currency depreciates against the GCU and the foreign currency appreciates. In the short run, the exchange rate between the two countries jumps to point 1 on the new ss path, and then the exchange rate falls and the relative price rises to point 2. This is the basic result from Dornbusch (1976) for two countries.

The effects of a strictly relative fiscal disturbance, an increase in $\mathrm{gr}_{\mathrm{r}}$ in equation (10), are shown in Figure 6 . We assume that the home government increases, and the other government decreases, expenditure on 
Figures

RELATIVE EFFECTS OF MONETAKY EXIXNSIOW

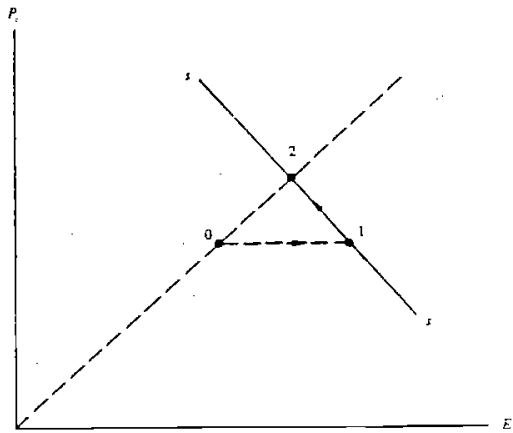

linvith

RIIAMVE EJHETS UF ITSCAL UISTLRBAVCE

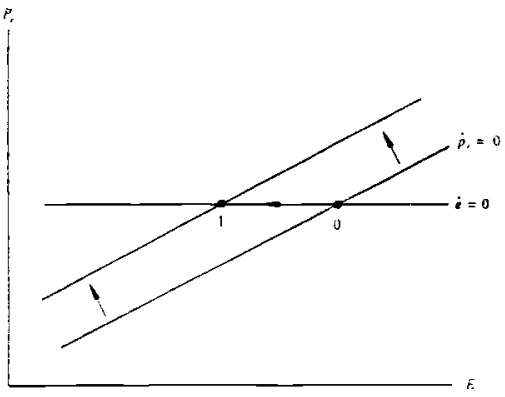

Fișure :

RELATIVE EFFECTS OF SLPPLY DISTLRBAXCE

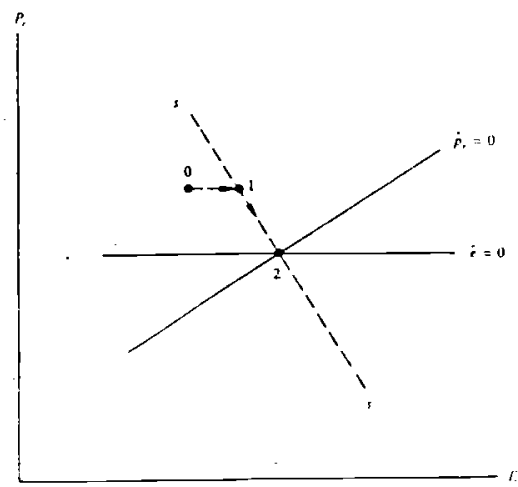


manufactures by the same amount. There is no change in the world market in manufactures or commodities, but in the relative model, the $\dot{p}_{r}-0$ line in Figure 6 shifts up. The equilibrium relative price level of the home country, where the fiscal expansion took place, increases for a given level of the exchange rate. There is no shift of the $\dot{e}-0$ line, since the fiscal variable does not enter the money-market equilibrium condition, equation (7). As a result, the exchange rate falls in a jump from point 0 to point 1 in Figure 6 . The home currency appreclates by enough to offset the effect of the fiscal shift on relative demand, with no effect on either price level in home currency. The nominal appreciation of the home currency produces a real appreciation of the same amount. This result is implicit in Dornbusch (1976), and explicit in Mundell (1963).

\section{The two models combined}

The model of the world markets in commodities and manufactures in GCU and the relative model of exchange rates and relative prices in home currencies can now be combined to analyze the effects of the various types of unanticipated disturbances originating in one country. We will consider, in turn, monetary, fiscal, and supply shocks. Monetary Expansion in One Country

First we illustrate the effects of an unanticipated monetary expansion in one country. At the level of the world model of commodity and manufactures prices, the results are illustrated in Figure 2. Measured in GCU, the commodity price jump, and then the manufactures price rises gradually, as the commodity price falls. The jump in the level of the commodity price leads the gradual increase in the manufactures price. 
Eventually both prices rise proportionately to the increase in the money stock, all measured in GCU.

The relative effect is shown in Figure 5. The exchange rate of the expanding country against the second country jumps from point 0 to point 1; that is, the expanding country's currency depreciates. Subsequently, that country's price level in home currency rises and its exchange rate falls, converging to point 2. In the new long-run equilibrium, the exchange rate and the price level in the expanding country rise proportionately to the monetary expansion.

\section{Fiscal Expansion in One Country}

The interesting case of an unanticipated fiscal expansion is one that alters world relative demand for manufactures and commodities, as well as the real exchange rate as shown in Figure 6 . To use a specific example, consider a fiscal expansion in the manufacturing country that increases the world relative demand for manufactures. As a convenient simplification, think of this country as Japan, and the other country, specializing in commodities production, as Italy. I/ The effects at the world level in GCU are shown in Figure 3. The commodity price jumps down, and then declines gradually further as the manufactures price rises. At the new equilibrium point $2, P_{m}$ has risen and $P_{c}$ has fallen, in GCU.

The relative effects are shown in Figure 6 . With no direct representation of the fiscal variable in the financial equilibrium equation (7), the $\dot{\mathrm{e}}=0$ line does not move. The fiscal expansion in Japan shifts the

1/ Table 9 below shows that among the large industrial countries, Japan is the least intensive in production of primary commodities, and Italy the most. 
$\dot{p}_{I}=0$ line left, moving the equilibrium point from 0 to 1 in a jump. The home real and nominal exchange rates appreclate, with no change in relative GDP deflators, in home currency. The appreciation of the yen just offsets the increase in $P_{m}$ in GCU, and the depreclation of the lira just offsets the fall in $P_{c}$ in GCU.

The effects of the fiscal expansion in the manufacturing country on prices in all three currencies are summarized in panel (a) of Table 1. $P_{m}$ is up and $P_{c}$ is down, in GCU. $P_{m}$ in lira rises both because of the increase in GCU and because of the depreciation of the lira against the GCU, while in yen $P_{m}$ is unchanged. $P_{c}$ is unchanged in 11 ra, while it falls in yen both from the fall in GCU and from the yen apprectation. Thus if both countries consume both goods, the CPI will fall in Japan and rise in Italy, reflecting the terms-of-trade effect, with both GDP deflators unchanged.

\section{Supply Expansion in One Country}

A supply shock also alters the world relative prices, as in Figure 3 , and the equilibrium real exchange rate. The analysis is slightly more complicated than that of a fiscal expansion, though, since both equilibrlum lines in Figure 6 shift with a supply shock. Consider an increase in productivity in the commodity-producing country (Italy) that increases the world relative supply of commodities. The effects at the level of the world market in GCU are again shown in Figure 3 . The commodity price jumps down from point 0 to point 1 when the supply increase becomes known to the market. Then $P_{c}$ falls gradually as $P_{m}$ rises to point 2 . In GCU the price of commodities falls and the price of manufactures rises. 
Table 1. Theoretical Effects on Prices from Varlous Disturbances $1 /$

(a)

Responses to a Fiscal Expansion in the Manufactures-Producing Country (Japan)

\begin{tabular}{cccc} 
& \multicolumn{3}{c}{ Measured in: } \\
\cline { 2 - 4 } Effect on & GCU & Lira & Yen \\
\hline$P_{m}$ & + & ++ & 0 \\
$P_{c}$ & - & 0 & - \\
\hline
\end{tabular}

(b)

Responses to a Supply Increase in the Commoditles-Producing Country (Italy)

(c)

Summary of Effects of Disturbances on Home-Currency Prices

Effects on Prices in:

Origlnating Country

\begin{tabular}{lcccccc} 
Shock & $P_{\mathrm{c}}$ & $\mathbf{P}_{\mathrm{m}}$ & $\mathrm{CPI}$ & $\mathbf{P}_{\mathrm{c}}$ & $\mathbf{P}_{\mathrm{m}}$ & $\mathrm{CPI}$ \\
\hline $\begin{array}{l}\text { Increase in Money Stock } \\
\text { in Either Country }\end{array}$ & + & + & + & 0 & 0 & 0 \\
$\begin{array}{l}\text { Fiscal Expansion In } \\
\text { Manufactures Producer }\end{array}$ & - & 0 & - & 0 & + & + \\
$\begin{array}{l}\text { Supply Increase in } \\
\text { Commodities Producer }\end{array}$ & - & + & $?$ & - & + & $?$ \\
\hline
\end{tabular}

1/ Price Increases are denoted by + and decreases by -; 0 Indicates no change. The symbols ++ and - : Indicate relatively large changes. 
The relative effects are shown in Figure 7 , with Italy as the home country. The productivity shock increases $y_{r}$ in both equations ( 7 ) and (10), shifting both equilibrium lines down. The $\dot{p}_{r}-0$ line shifts down by a factor of $-1 / \delta$ from equation (10), and the $\dot{e}-0$ line shifts down by - $\phi$ from equation (7). If the shift in the $\dot{p}_{r}-0$ line is sufficiently larger than the shift in the $\dot{e}-0$ line, the new saddle path will pass to the right of the original equilibrium point 0 , as shown in Figure 7 . This would be the case if the supply shock's effects were felt mainly in the goods markets, compared with the effects in the money market via an increase in income. In this case, the exchange rate of Italy would jump up to point 1 , and then $r$ ise further as $P_{r}$ falls to point 2 . That is, the lira would depreciate in both nominal and real terms against the GCU.

One cannot rule out the possibility that the downward shift in the $\dot{e}$ - 0 line would be large enough that the new saddle path would pass to the left of point 0 . In that case the exchange rate could jump down, and then rise as $P_{r}$ fell to the new equilibrium. Equation (10) shows that in the new equilibrium the real exchange rate (e - $p_{r}$ ) must rise with an increase in $y_{r}$ by $d\left(e-p_{r}\right) / d y_{r}-1 / \delta$. We know, therefore, that in Figure 7, along the new equilibrium line $\dot{p}_{r}-0$ the lira has depreciated in real terms, regardless of the direction of its original jump. So the result from the relative model is that the real exchange rate of the country with the positive supply shock rises (home currency depreciates) relative to the GCU, and the other country's real exchange rate falls.

The results for the positive supply shock in the commodity-producing country are summarized in panel (b) of Table 1 . The price of commodities falls and the price of manufactures rises in GCU. With the lira 
depreciating in real terms, the lira price of manufactures rises even more, and the lira price of commodities falls less than in GCU. As the yen appreciates in real terms, the yen price of commodities falls even more, and the yen price of manufactures rises less, than in GCU. With the two prices moving in opposite directions in both currencles, the effects on the two CPIs are ambiguous. However, since the movement in the real exchange rate adds to the downward movement in commodity prices in Japan, and to the upward movement of manufactures prices in Italy, it seems likely the the CPI would fall in Japan and rise in Italy.

\section{Summary}

The effects of the unanticipated disturbances in single countries are summarized in panel (c) of Table 1. The effects of an unanticipated expansion in the money supply are familiar. In the home country, prices rise proportionately to the expansion. The currency of the foreign country appreciates, and local currency prices in the foreign country are unchanged. In this case the commodity price jumps and leads a general inflation in the home country.

The effects of a fiscal expansion or a supply shock are less familiar. A fiscal expansion in the manufacturing country that raises world relative demand for manufactures raises the GCU price of manufactures and reduces the GCU price of commodities. It also appreciates the currency of the expanding country and depreciates the currencles of the others, in nominal and real terms. The result is a negative effect on the CPI in the expanding country and a positive effect on the others, owing to the movement of the exchange rate. This is similar to the effect of the fiscal expansion in the United States on the U.S. Inflation rate via the 
dollar exchange rate in the early 1980s. In this case the downward jump in the commodity price following the disturbance contains no general signal for inflation unless it includes a general shift in monetary policy. If unaccommodated fiscal disturbances are randomly distributed across countries and over time, they will create noise in the relation between commodity price movements and subsequent inflation.

Finally, a positive supply shock lowers the price of the good whose supply has increased and depreciates the currency of the suppliers in real terms. The net result is to reduce the price of the good in question, and increase the prices of the others, in all currencies. The effects on home-currency CPIs deperd on the weights of the goods in the CPI. In this case the inftial downward jump in the GCU commodity price also contains no signal for subsequent inflation. By using an index over a large number of commodities, individual supply shocks such as these are averaged out to some degree in the empirical work that follows.

\section{Country-Specific Commodity Price Indexes}

The empirical tests developed in Sections IV and $V$ of this paper evaluate the relationships between general movements in world prices of primary commodities and inflation in the large industrial countries. In order to isolate the effects of global developments on individual countries, it is necessary to develop separate commodity-price indexes for each country. This task has two dimensians: determining the weights that each commodity should have in a country's index, and denominating the index in that country's currency. The first dimension is at least potentially important in order to take account of variation between countries in the shares of key commodities in consumption patterns; the second 
ensures that the commodity-price and general-price indexes are denominated in the same currency units.

The commodity-price indexes have been constructed using spot prices for major commodities and weights that reflect the pattern of consumption of these commodities in each country. A large number of price quotations are included (thirty-one primary commodities represented by thirty-six international price quotations), in order to minimize the effects of price fluctuations caused by supply shocks or other real disturbances in individual commodity markets. Weights are based on consumption, rather than production or imports, since these relate most directly to movements in the consumer price index.

Table 2 provides a comparison of patterns of consumption of primary commodities in the seven major industrial countries. 1 / These data indicate that the portion of total private consumption attributed to the consumption of primary commodities $2 /$ is quite uniform among countries, at about 8 percent (second row of Table 2). Consumption of individual commodities, however, varies substantially from country to country. For example, while the consumption of grains is relatively constant as a share of primary consumption for most countries (about 14 percent except for Germany), the composition of grain consumption is more diversified. Weights representing the consumption of wheat in France, Italy, and the United Kingdom (each 10 percent); maize in the United States (11 percent);

1 Data sources and methodology are described in an appendix, available on request.

2) This statement refers to the ratio of the value of consumption of the 31 selected primary commodities to the value of total private consumption. 
Table 2. Consulption of Primary Commodities in Major Industrial countries, 1983-85

\begin{tabular}{lllllll}
\hline Commodity & Canada & France Germany & Italy & Japan & $\begin{array}{l}\text { United Kingdom } \\
\text { States }\end{array}$ & G-7 \\
\hline
\end{tabular}

Total, All Primary Comnodities

In millions of U.S. dollars

(yearly average)
in percent of total
consumption

17,515

$27,749 \quad 36,225 \quad 24,545$

$8.9 \quad 9.7 \quad 9.4$

55,566

$22,284 \quad 183,172 \quad 367,055$

9.0

7.5

$8.1 \quad 7.5$

$\mathbf{8 . 0}$

Weights (in percent)

\begin{tabular}{|c|c|c|c|c|c|c|c|c|}
\hline $\begin{array}{c}\text { Cereals } \\
\text { Wheat } \\
\text { Maize } \\
\text { Rice }\end{array}$ & $\begin{array}{r}10.5 \\
4.2 \\
6.2 \\
0.1\end{array}$ & $\begin{array}{r}14.0 \\
9.8 \\
4.0 \\
0.2\end{array}$ & $\begin{array}{l}6.5 \\
5.3 \\
1.1 \\
0.1\end{array}$ & $\begin{array}{r}16.3 \\
9.6 \\
5.1 \\
1.7\end{array}$ & $\begin{array}{r}15.5 \\
2.2 \\
4.1 \\
9.2\end{array}$ & $\begin{array}{r}11.3 \\
10.1 \\
1.1 \\
0.0\end{array}$ & $\begin{array}{r}15.4 \\
3.3 \\
11.1 \\
1.0\end{array}$ & $\begin{array}{r}14.0 \\
4.7 \\
7.3 \\
2.0\end{array}$ \\
\hline $\begin{array}{l}\text { Vegetable oils } \\
\text { Soybeans } \\
\text { Soybean meal } \\
\text { Soybean oil } \\
\text { Polm oll } \\
\text { Coconut oil } \\
\text { Groundnut oil }\end{array}$ & $\begin{array}{l}3.1 \\
0.8 \\
1.5 \\
0.6 \\
0.1 \\
0.1 \\
0.0\end{array}$ & $\begin{array}{l}4.3 \\
0.3 \\
3.0 \\
0.2 \\
0.1 \\
0.2 \\
0.5\end{array}$ & $\begin{array}{l}4.4 \\
0.8 \\
2.1 \\
0.8 \\
0.2 \\
0.3 \\
0.1\end{array}$ & $\begin{array}{l}4.1 \\
0.7 \\
2.2 \\
0.7 \\
0.2 \\
0.1 \\
0.1\end{array}$ & $\begin{array}{l}3.6 \\
1.3 \\
1.2 \\
0.8 \\
0.2 \\
0.1 \\
0.0\end{array}$ & $\begin{array}{l}3.0 \\
0.3 \\
1.5 \\
0.6 \\
0.5 \\
0.1 \\
0.0\end{array}$ & $\begin{array}{l}5.7 \\
1.9 \\
2.0 \\
1.5 \\
0.1 \\
0.2 \\
0.0\end{array}$ & $\begin{array}{l}4.8 \\
1.4 \\
1.9 \\
1.1 \\
0.1 \\
0.2 \\
0.1\end{array}$ \\
\hline $\begin{array}{l}\text { Meat } \\
\text { Beef } \\
\text { Lemb }\end{array}$ & $\begin{array}{r}14.5 \\
14.3 \\
0.2\end{array}$ & $\begin{array}{r}18.6 \\
17.0 \\
1.6\end{array}$ & $\begin{array}{l}9.7 \\
9.6 \\
0.3\end{array}$ & $\begin{array}{r}16.2 \\
15.5 \\
0.6\end{array}$ & $\begin{array}{l}2.6 \\
2.4 \\
0.3\end{array}$ & $\begin{array}{r}15.1 \\
11.7 \\
3.4\end{array}$ & $\begin{array}{r}14.9 \\
14.8 \\
0.2\end{array}$ & $\begin{array}{r}12.9 \\
12.4 \\
0.5\end{array}$ \\
\hline $\begin{array}{l}\text { Sugar } \\
\text { Bananas }\end{array}$ & $\begin{array}{l}0.7 \\
0.5\end{array}$ & $\begin{array}{l}2.8 \\
0.5\end{array}$ & $\begin{array}{l}2.3 \\
0.5\end{array}$ & $\begin{array}{l}2.5 \\
0.5\end{array}$ & $\begin{array}{l}0.7 \\
0.6\end{array}$ & $\begin{array}{l}4.0 \\
0.5\end{array}$ & $\begin{array}{l}2.0 \\
0.5\end{array}$ & $\begin{array}{l}2.0 \\
0.5\end{array}$ \\
\hline $\begin{array}{c}\text { Beverages } \\
\text { Coffee } \\
\text { Cocos } \\
\text { Tea }\end{array}$ & $\begin{array}{l}2.2 \\
1.4 \\
0.6 \\
0.2\end{array}$ & $\begin{array}{l}3.9 \\
2.8 \\
1.1 \\
0.1\end{array}$ & $\begin{array}{l}6.2 \\
3.8 \\
2.2 \\
0.1\end{array}$ & $\begin{array}{l}3.8 \\
2.9 \\
0.8 \\
0.0\end{array}$ & $\begin{array}{l}1.9 \\
1.1 \\
0.3 \\
0.5\end{array}$ & $\begin{array}{l}4.8 \\
1.3 \\
1.6 \\
1.9\end{array}$ & $\begin{array}{l}2.4 \\
1.6 \\
0.7 \\
0.1\end{array}$ & $\begin{array}{l}3.0 \\
1.9 \\
0.9 \\
0.3\end{array}$ \\
\hline $\begin{array}{l}\text { Agricultural Raw Moterials } \\
\text { Timber } \\
\text { Fibers } \\
\text { Cotton } \\
\text { Wool } \\
\text { Notural rubber } \\
\text { Tobacco } \\
\text { Hides }\end{array}$ & $\begin{array}{l}19.1 \\
16.1 \\
0.6 \\
0.5 \\
0.1 \\
0.5 \\
1.6 \\
0.5\end{array}$ & $\begin{array}{r}15.2 \\
9.9 \\
2.2 \\
1.0 \\
1.3 \\
0.5 \\
1.5 \\
1.0\end{array}$ & $\begin{array}{r}24.8 \\
20.3 \\
1.5 \\
1.0 \\
0.6 \\
0.5 \\
0.9 \\
1.5\end{array}$ & $\begin{array}{c}14.8 \\
5.8 \\
3.7 \\
1.8 \\
1.3 \\
0.6 \\
1.9 \\
3.6\end{array}$ & $\begin{array}{r}21.1 \\
15.3 \\
3.9 \\
2.1 \\
0.9 \\
0.9 \\
1.2 \\
0.6\end{array}$ & $\begin{array}{r}18.4 \\
12.7 \\
2.7 \\
0.4 \\
2.4 \\
0.5 \\
1.2 \\
1.2\end{array}$ & $\begin{array}{r}11.5 \\
7.7 \\
1.3 \\
1.1 \\
0.2 \\
0.4 \\
1.0 \\
1.1\end{array}$ & $\begin{array}{r}15.5 \\
10.8 \\
1.8 \\
1.2 \\
0.6 \\
0.5 \\
1.2 \\
1.2\end{array}$ \\
\hline $\begin{array}{l}\text { Metals and Phosphate Rock } \\
\text { Copper } \\
\text { Aluninu } \\
\text { Iron ore } \\
\text { Tin } \\
\text { Nickel } \\
\text { Zinc } \\
\text { Leed } \\
\text { Phosphate Rock }\end{array}$ & $\begin{array}{l}0.6 \\
1.8 \\
2.2 \\
2.2 \\
0.3 \\
0.2 \\
0.7 \\
0.2 \\
0.7\end{array}$ & $\begin{array}{l}9.7 \\
2.1 \\
2.7 \\
2.2 \\
0.6 \\
0.6 \\
0.8 \\
0.3 \\
0.7\end{array}$ & $\begin{array}{l}13.3 \\
3.1 \\
3.9 \\
3.3 \\
0.6 \\
1.0 \\
0.9 \\
0.4 \\
0.2\end{array}$ & $\begin{array}{l}8.2 \\
2.1 \\
2.3 \\
1.9 \\
0.2 \\
0.4 \\
0.7 \\
0.4 \\
0.3\end{array}$ & $\begin{array}{l}16.6 \\
3.3 \\
3.8 \\
5.8 \\
0.7 \\
1.1 \\
1.1 \\
0.3 \\
0.2\end{array}$ & $\begin{array}{l}8.7 \\
2.3 \\
1.9 \\
1.8 \\
0.5 \\
0.6 \\
0.7 \\
0.5 \\
0.3\end{array}$ & $\begin{array}{l}7.4 \\
1.6 \\
2.9 \\
1.0 \\
0.3 \\
0.4 \\
0.4 \\
0.3 \\
0.5\end{array}$ & $\begin{array}{l}9.7 \\
2.1 \\
3.0 \\
2.2 \\
0.6 \\
0.6 \\
0.7 \\
0.3 \\
0.4\end{array}$ \\
\hline Petroleu 1/ & 49.0 & 30.9 & 32.5 & 33.8 & 37.9 & 34.2 & 40.2 & 37.6 \\
\hline
\end{tabular}

Sources: see text and Appendix I (available on request).

$1 / 1986$ data. 
and rice in Japan ( 9 per ent) are significantly higher than average consumption of these commodities by the group of seven countries.

Similarly, beef consumption is relatively low in Japan (2.4 percent) and Germany ( 9.4 percent), compared with the group ( 12.4 percent); these two countries consume relatively more seafood and pork products, respectively, which are not included in the indexes. 1/ Tea consumption, as might be expected, is relatively high in the United Kingdom ( 1.9 percent), as is coffee consumption in Germany ( 3.8 percent). The relatively low level of consumption of timber products in Italy ( 5.5 percent) reflects a preference for stone and cement in housing construction, compared with a greater preference for timber in construction in Germany (20.3 percent).

There is remarkable consistency in the share of consumption of primary commodities attributed to petroleum, which--at roughly 38 percent--is the largest of any commodity by far. Weights for petroleum were based on consumption and import unit values in 1986, rather than the 1983-85 average that was used for all other commodities. This ad hoc procedure is intended to avoid overstating the importance of petroleum, in light of the very sharp decline in oil prices that occurred in 1986 and again in 1988. 2

A caveat on the estimates of the pattern of consumption in the large industrial countries relates to the difficulty in separating end-use consumption of primary commodities from intermediate use in the production of other primary commodities or manufactured products for export. Some

1. Broadly representative and timely price series are not available for seafood or pork products.

2) The use of average 1983-85 data would give a weight to petroleum of around 50 percent in each country. 
adjustments were made to consumption values to avoid double counting of commodities at various stages of production, such as in the production of soybean and timber products. 1 / It was not generally possible, however, to adjust for the consumption of one commodity in the production of another. Hence there is sone double counting for all countries, on account of maize and soybean meal used as cattle feed, and phosphate rock used in the production of grains, soybeans, and fibers.

Consumption weights also may be overestimated for a few commodities in countries where there are significant exports of finished manufactures. Relatively high weights for metals in Japan (16.4 percent) and Germany (13.3 percent) compared with the group average ( 9.7 percent) reflect a greater rate of production of automobiles, more than half of which are exported. Relatively high weights for hides in Italy ( 3.3 percent) and sugar and cocoa in Germany (about 2 percent each) reflect the production of shoes and confectionery for export in these countries. The bias in the indexes caused by overestimated weights may not extend to the estimation of weights for the group of countries, however, since manufactures exported by one country are often imported by another country in the group. In addition, some underestimation of weights occurs, when commod-

1 The consumption weights in Table 1 were modified to prevent double counting of soybeans and soybean meal production; logs, timber, plywood. and paperboard production; and tobacco and cigarette production. The last two adjustments were needed to account for the export of commodities at a higher value-added level (principally plywood and paper exports from Canada and cigarette exports from the United States). 
ities are imported at an advanced stage of production from outside the group of seven countries. $1 /$

A comparison of commodity price indexes, using weights from Table 2 and denominating commodity prices in a common currency, is presented in Chart 1. A casual inspection reveals the indexes to be quite similar, despite the differences in weights used to construct them. In particular, indexes for all countries that include large, similar weights for petroleum are found to be roughly identical, with only. minor variations evident in the indexes that exclude petroleum. These variations, in turn, are caused by the presence or absence of large weights for commodities whose prices moved differently than did prices of the group.

As examples of differences in movements in prices, indexes for most countries rose in $1973-74$ to 80 percent or more of their respective 1980 levels, largely owing to a more than doubling of grain prices from 1972 . The exception to this was the price index for Germany, which remained below 80 , on account of a weight for grains equal to roughly one half of that in other countries. Other distinctive movements in Germany's index include a sharp, extended rise in the index during 1978-80, owing in part to a doubling of the international price of logs, and a subsequent rise in 1988, to well over 100 percent of the 1980 level, again related to a rise

1) An example of underestimation of weights is given by iron ore, which is often imported and consumed as steel products. An adjustment to the iron ore weight to account for the import of steel products is difficult because of the variety of these products and their high value-added component; the value of steel at an advanced stage of production (cold rolled steel) is ten times that of iron ore. The United States is a significant importer of semi-finished and finished steel products, with an apparent consumption nearly equal to that of Japan, in tonnage terms; this compares with an estimated weight for iron ore consumption in the United States that is about one fifth that in Japan. 


$$
-24 a-
$$

Chart 1. Seven Large Industrial Countries: Commodity Prices, In a Common Currency, 1957-88.

(Index : $1980=100$ )
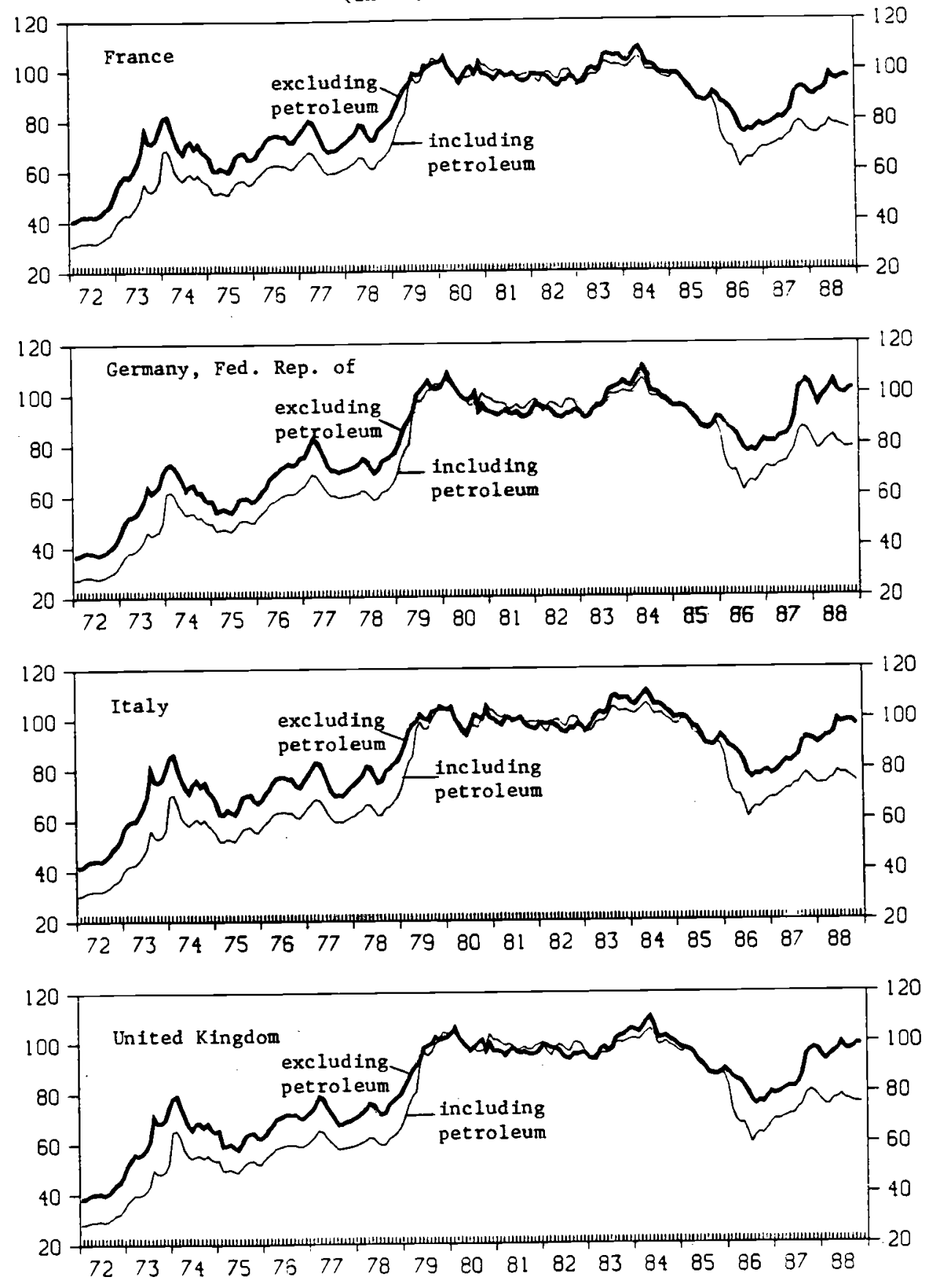
Chart 1 (continued). Seven large Industrial Countries: Commodity Prices, In a Common Currency, 1957-88.

(Index: $1980=100$ )
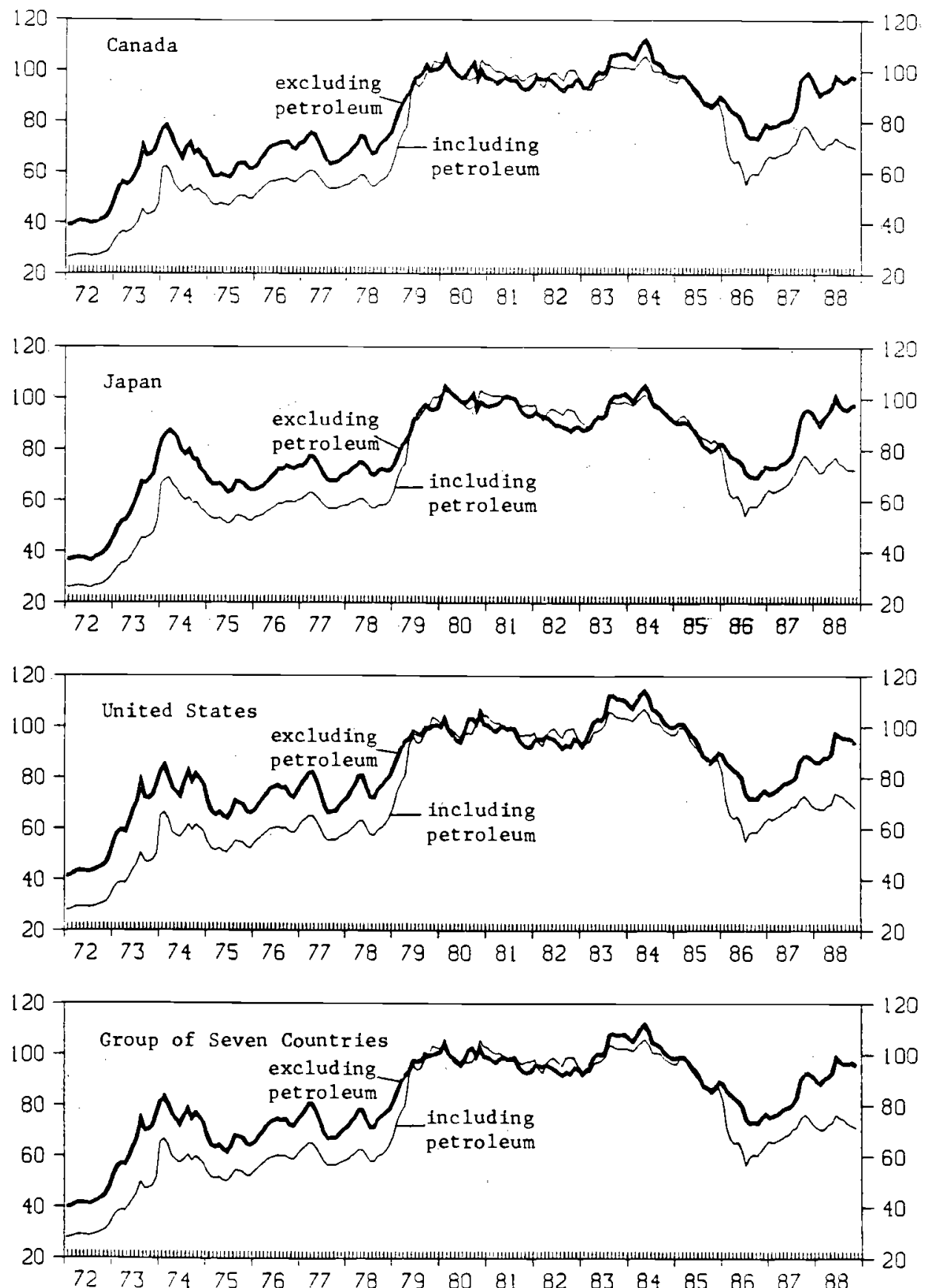
This paper has illustrated the tradeoffs policy makers would face when choosing the width of a band, or when converging to an extremely narrow band In order to shift to a unique currency. These tradeoffs concern the degree of exchange- rate, interest-rate and fundamentals variability. They depend on the assumed process (constant drift or mean reversion) for the disturbances which affect money demand and/or supply.

They also depend on the type of coordination which would take place in case of foreign exchange crisis. In this last respect, we have been careful to make Assumption 2 so as to avoid altogether the problem of speculative attacks and needed reserves. We have assumed that central banks credibly and unconditionally intervene so as prevent speculative attacks. Indefinite intervention is possible if the central bank of the currently strong currency supports the other currency by printing money.

We have generalized the result of Svensson (1989) that the variability of the exchange rate is translated into variability in the interest rate differential.

We have also found that the degree of fundamentals variability which would be tolerated by the market when a target zone is extremely narrow is very large (a difference of two orders cf magnitude) in the case of a constant drift disturbance and in the case of mean reversion with a band exactly centered on the reversion point. The result is lost if the band is not precisely centered there. 
APPENDIX A

MODEL INTERPRETATION

It is conceivable to interpret $v$ either as a supply or a demand shock. Consider the following two-country log-linear monetary exchange rate model which has been extensively used in recent work (see for example Delgado and Dumas (1990) and all the references given there).

$$
\begin{aligned}
& \bar{m}=\ln (D+R)+z_{1}-m+z_{1} \\
& \dot{m}^{\star}=\ln \left(D^{\star}+R^{*}\right)+z_{1}^{*}=m^{*}+z_{1}^{*} \\
& \tilde{m}-p=\phi y-\gamma \dot{p}+z_{2} \\
& \bar{m}^{\star}-p^{*}-\psi y^{*}-\gamma i^{*}+z_{2}^{*} \\
& 1=i *+E[d S \mid \Phi(t)\} / d t+z_{3}
\end{aligned}
$$

All starred varlables are the forelgn variables corresponding to the nonstarred domestic variables. $z_{1}$ being a multiplicative shock which affects (D+ R) and is assumed to follow a geometric Brownian motion process, $z_{1}$ is the $10 \mathrm{~g}$ of $z_{1} \cdot 11$ in is the total money supply that can be broken down into two components, m the controllable money supply, and $z_{1}$ the uncontrollable component. The right-hand sides of equations (A3) and (A4) are money demands; $z_{2}$ and $z_{2}^{*}$ are money demand shocks. $p$ is the price level. $y$ is domestic output. $i$ is the domestic interest rate.

$E$ is the expectations operator. $\Phi(t)$ is the information set used by

${ }^{11}$ In the classic speculative attack 1iterature (Krugman (1979) and Flood and Garber (1983); see also Dornbusch (1984) and Claessens (198(A3)], shocks came from growth in domestic credit. In our formulation, the terms $z_{1}$ and $z_{1}^{*}$ are shocks applied to the sum of $R$ and $D$, not to $D$. 
(1989a, b) put it, all information regarding not only the evolution of the variables in the system (Al)-(A5), but the implicit as well as explicit government policies regarding exchange rate regimes in particular and monetary policy in general. Of importance for our purposes is the market perception that once the central bank whose currency is weak runs out of reseves, the other central bank will continue intervention to support the weak currency.

Subtracting (A3) from (A4) and replacing (A1), (A2) and (A3) we can obtain equation $(1)$, where $v-\left(z_{1}-z_{1}^{\star}\right)+\psi\left(y-y^{\star}\right)+\left(z_{2}-z_{2}^{\star}\right)+z_{3}$ is a cumulative shock. Given that $v$ includes terms in $z_{1}$ and $z_{1}^{\star}$ it can be interpreted as either a demand or a supply shock to money. 


$$
\mathrm{NF}(\overline{\mathrm{X}}, \mathrm{X})=-\beta \mathrm{e}^{\alpha \overline{\mathrm{X}}-\beta \mathrm{X}}-\alpha \mathrm{e}^{\alpha \mathrm{X}-\beta \overline{\mathrm{X}}}+(\alpha+\beta) \mathrm{e}^{(\alpha-\beta) \overline{\mathrm{X}}}
$$

$$
\mathrm{NG}(\overline{\mathrm{X}}, \underline{\mathrm{X}})=\alpha \mathrm{e}^{\alpha \overline{\mathrm{X}} \cdot \beta \underline{\mathrm{X}}}+\beta \mathrm{e}^{\alpha \underline{\mathrm{X}} \cdot \beta \overline{\mathrm{X}}}-(\alpha+\beta) \mathrm{e}^{(\alpha-\beta) \underline{\mathrm{X}}}
$$

$$
D F(\bar{X}, X)=-\alpha \beta\left(e^{\alpha \overline{\mathrm{X}}-\beta \underline{X}}-\mathrm{e}^{\alpha \mathrm{X}-\beta \overline{\mathrm{X}}}\right)
$$

$$
F(\bar{X}, \underline{X} ; \bar{S}, \underline{S})=-\bar{X}+\bar{S}-\gamma \mu+N F(\bar{X}, \underline{X}) / D F(\bar{X}, \underline{X})=0
$$

$$
G(\bar{X}, \underline{X} ; \bar{S}, \underline{S})--X+\underline{X}-\gamma \mu+N G(\bar{X}, \underline{X}) / D F(\bar{X}, \underline{X})-0
$$

Using the implicit function theorem for $F(\cdot)=0$ and $G(\cdot)-0$ we can obtain the two derivatives $\partial \overline{\mathrm{X}} / \partial \dot{\mathrm{S}}$ and $\partial \underline{\mathrm{X}} / \partial \underline{\mathrm{S}}$ which we are looking for.

Defining the following functions

$$
\begin{aligned}
& F_{x 1}(\cdot)=\partial F(\cdot) / \partial \bar{x} \\
& F_{x 2}(\cdot)=\partial F(\cdot) / \partial \underline{X} \\
& G_{x 1}(\cdot)=\partial G(\cdot) / \partial \bar{x} \\
& G_{x 2}(\cdot)=\partial G(\cdot) / \partial \underline{X} \\
& F_{s I}(\cdot)=\partial F(\cdot) / \partial \underline{S} \\
& F_{s 2}(\cdot)=\partial F(\cdot) / \partial \underline{S},
\end{aligned}
$$


we can determine the signs of the following expressions

$$
\begin{aligned}
& \partial \overline{\mathrm{X}} / \partial \overline{\mathrm{S}}-\left[\begin{array}{ll}
F_{\mathrm{S} 1} & F_{\times 2} \\
G_{S 1} & G_{\times 2}
\end{array}\right] / J \geq 0 \\
& \partial \underline{x} / \partial \underline{s}-\left[\begin{array}{cc}
F_{x 1} & F_{s 2} \\
G_{x 1} & G_{s 2}
\end{array}\right] / J \geq 0
\end{aligned}
$$

where:

$$
J=\left[\begin{array}{ll}
F_{x 1} & F_{x 2} \\
G_{x 1} & G_{x 2}
\end{array}\right]>0
$$

Replacing all definitions in (B12) and (B13), and remembering that $1 / \alpha$. $1 / \beta=\gamma \mu$, we obtain the signs of the partial derivatives. Q.E.D. 
APPENDIX C

ASYMPTOTIC BEHAVIOR FOR WIDE BANDS

UNDER CONSTANT DRIFT

Let us call $\delta$ the joint asymptotic value of the distance of $\bar{x}$ from the diagonal line and of the distance of $\underline{x}$ from the free-float line; let us also cal1 $2 \varepsilon$ the width of the exchange rate band, $\overline{\mathrm{S}}=\mathrm{S}_{0}+\varepsilon$ and $\mathrm{S}=\mathrm{S}_{0}-\epsilon$. We have:

$$
\begin{aligned}
& \overline{\mathrm{X}}-\mathrm{S}_{0}+\varepsilon+\delta \\
& \underline{\mathrm{X}}-\mathrm{S}_{0}-\varepsilon-\gamma \mu-\delta \quad \text { and } \\
& \underline{\mathrm{X}}=\overline{\mathrm{X}}-2(\varepsilon+\delta)-\gamma \mu
\end{aligned}
$$

To study the behavior of wide bands we can substitute these relationships into (14), simplify, and neglect terms that approach zero as we make $\delta, c \rightarrow \infty$. We obtaln a simple relationship: 12

$$
\delta-\epsilon-\gamma \mu+1 / \alpha=\varepsilon+1 / \beta
$$

Q.E.D.

${ }^{12}$ Svensson obtained a similar relationship for the special case of zero drift $(\mu-0)$ In which the two roots are of equal magnitude: $\alpha-0_{-} \beta$. The distance from the free-float (confounded in his case with the $45^{\circ} 11$ ne) was $1 / \alpha--1 / \beta$. 
CUBIC RELATIONSHIP FOR NARROW BANDS BETWEEN

THE BAND ON FUNDAMENTALS AND THE BAND ON THE EXCHANGE RATE

UNDER CONSTANT DRIFT

To obtain the relationship between the widths of the bands for small widths we are going to use a linear approximation to the exponential function:

$$
\mathbf{e}^{\lambda \mathbf{x}} \approx 1+\lambda \mathbf{x}+(\lambda \mathbf{x})^{2} / 2 !+(\lambda x)^{3} / 3 !+\ldots
$$

The expansion is carried out as far as is needed. Additional terms are added if the prior order terms vanish or lead to an identity.

We proceed with the linearization around $s_{0}$. The four variables with respect to which the linearization is to be performed can be written as:

$$
\begin{aligned}
& \bar{s}-s_{0}+\epsilon \\
& \underline{s}=s_{0}-\epsilon \\
& \bar{x}=s_{0}+\bar{\delta} \\
& \underline{x}=s_{0}-\underline{\varepsilon}
\end{aligned}
$$

Replacing (D2)-(D5) in (A14)-(A15) the system is written as:

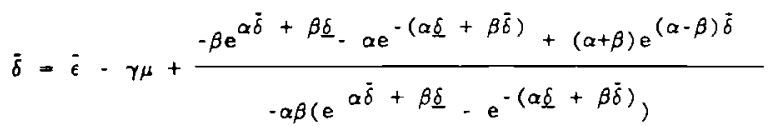


$\mathrm{X}-\underline{S}-\gamma \mu+\frac{\alpha \mathrm{e}^{\alpha \bar{\delta}+\beta \bar{\delta}}+\beta \mathrm{e}^{-(\alpha \underline{\delta}+\beta \bar{\delta})} \cdot(\alpha+\beta) \mathrm{e}^{-(\alpha-\beta) \underline{\delta}}}{-\alpha \beta\left(\mathrm{e}^{\alpha \bar{\delta}+\beta \underline{\delta}} \cdot \mathrm{e}^{-(\alpha \underline{\delta}+\beta \bar{\delta})}\right)}$

The last two equations can also be written in matrix form as

$$
\left[\begin{array}{c}
\epsilon \\
-\epsilon
\end{array}\right]\left[\begin{array}{c}
\gamma \mu+\delta \\
\gamma \mu-\underline{\delta}
\end{array}\right]+\left[\begin{array}{ll}
e^{\alpha \bar{\delta}} & e^{-\beta \bar{\delta}} \\
e^{-\alpha \delta} & e^{\beta \delta}
\end{array}\right]\left[\begin{array}{cc}
1 / \alpha & 0 \\
0 & -1 / \beta
\end{array}\right]\left[\begin{array}{ll}
e^{\alpha \bar{\delta}} & e^{-\beta \bar{\delta}} \\
e^{-\alpha \delta} & e^{\beta \delta}
\end{array}\right]\left[\begin{array}{c}
-1 \\
-1
\end{array}\right]
$$

Using $\gamma \mu-1 / \alpha-1 / \beta$ and expanding (D8), the following expression is obtained:

$\epsilon \approx(\alpha+\beta)^{2}(\bar{\delta}+\delta)^{3} / 12$

Q.E.D. 


\section{REFERENCES}

Abramowitz, Milton and Irene A. Stegun editors, Handbook of Mathematical Functions, New York: Dover, 1972

Claessens, Constantifn, "Balance of Payments Crises, " Unpublished Dissertation, University of Pennsylvania. 1986

Delgado, Francisco and Bernard Dumas, "Monetary Contracting Between Central Banks and the Design of Sustainable Exchange-Rate Zones," Working Paper No. 3440, NBER. September 1990.

Dornbusch, Rudiger, "Collapsing Exchange Rate Regimes," Working Paper, M.I.T. September 1984 .

Dumas, Bernard, "Hysteresis in Gapital Formation," Wharton School working paper, July 1988, revised as: "Perishable Investment and Hysteresis in Capital Formation," Working Paper NO. 2930, NBER. April 1989.

Flood, Robert P. and Peter M. Garber, "A model of Stochastic Process Switching," Econometrica Vo1. 5, Number 3, May 1983, pp 537-552.

Flood, Robert P. and Peter M. Garber, "The linkage Between Speculative Attack and Target Zone Models of Exchange Rate," Working Paper NO. 2918, NBER. April 1989.

Froot, Kenneth A. and Maurice Obsfeld, "Stochastic Process Switching: Some Simple Solutions," Working Paper NO, 2998, NBER. June 1989, Econometrica forthcoming.

Froot, Kenneth A. and Maurice Obsfeld, "Exchange-Rate Dynamics under Stochastic Regime Shifts: A Unified Approach," Mimeo IMF, June 1989.

Krugman, Paul, "A Model of Balance-of-Payments Crisis," Journal of Money Credit and Banking, Vol. 11 No. 3, August 1979, pp 311-325.

Krugman, Paul, "Target Zones and Exchange Rate Dynamics," Quarterly Journal of Economics, 1990.

Krugman, Paul and Julio Rotemberg, "Target Zones With Limited Reserves," Mimeo M.I.T. August 1989, revised August 1990, this volume.

Lewis, Karen, "Occasional Interventions to Target Rates with a Foreign Exchange Application," working paper, New York University, 1990.

Miller, M. and P. Weller, "Target Zones, Currency Options and Monetary Policy," Mimeo 1988, University of Warwick.

Svensson, Lars E. O., "Target Zones and Interest Rate Variability: Where does the Variability Go, and Is a Fixed Exchange Rate Regime The Limit of a Narrow Target Zone," Mimeo, Institute for International Economic Studies, University of Stockholm. August 1989 . 
Figure 1: Target zones of different widths

The figure is constructed by changing the width of the band around $s_{0}-4.5$. This means solving the system (14)-(15) for different values of $\bar{S}$ and $\underline{S}$ positioned symmetrically around $s_{0}$. The two straight lines in the middle are the $45^{\circ}$ diagonal line which contains the fixed exchange points, and the free float. The thick line is the locus of tangencies implied by the smooth pasting conditions. Points above $s_{0}$ are pairs $\left(\bar{x},{ }^{-}\right)$; points below $s_{0}$ are pairs $(\underline{X}, \underline{S})$. Numerical values of parameters are: $\sigma^{2}=0.25, \mu-0.5$ and $\gamma=$ 0.5 . Units on the two axes are not the same.

Figure 2: Extreme values of interest rate differential The figure is constructed by changing the width of the exchange rate band symmetrically around $s_{0}=4.5$. Points above $S_{0}$ have abscissae equal to $\bar{x}$ and ordinates equal to the interest rate differential (assumed equal to the conditionally expected exchange rate change) reached when $X-\bar{x}$. Points below $S_{0}$ have abscissae equal to $\underline{X}$ and ordinates equal to the interest rate differential (assumed equal to the conditionally expected exchange rate change) reached when $X-\underline{X}$. Numerical values of parameters are: $\sigma^{2}=0.25, \mu-$ 0.5 and $\gamma=0.5$.

Figure 3: Exchange rate and interest rate differential

When the band is wide as in the case of this figure $(\underline{s}-1.999, \bar{s}=7.001$ ), the exchange-rate curve follows the free-float line and the interest-rate curve is flat over most of the range of allowed variations. Numerical values of parameters are: $\sigma^{2}=0.25, \mu=0.5$ and $\gamma=0.5$. 
Figure 4: Exchange rate and interest rate differential

When the band is narrow as in the case of this figure (ㅁ $-4.4999, \dot{\mathbf{S}}=$ 4.5001), the exchange-rate curve is $\mathrm{S}$-shaped and is situated far from the free-float line. The interest-rate curve is practically a straigtht line reflecting the imminent intervention. Numerical values of parameters are: $\sigma^{2}-$ $0.25, \mu=0.5$ and $\gamma=0.5$.

Figure 5: Target zones of different widths: mean reverting case; symmetric solution with reversion point $A_{0}=7.8$.

The figure is constructed by changing the width of the band around $s_{0}-A_{0}$ 7.8. This means solving the system (26) for different values of $\overline{\mathrm{s}}$ and $\mathbf{s}$ positioned symmetrically around $S_{0}=A_{0}$. The two straight lines in the middle are the $45^{\circ}$ diagonal line which contains the fixed exchange points, and the free float which is not at a $45^{\circ}$ incline in this case. The thin curve is an example of an exchange rate curve. The thick line is the locus of tangencies Implied by the smooth pasting conditions. Polnts above $s_{0}$ are palrs ( $\left.\overline{\mathrm{X}}, \overline{\mathrm{S}}\right)$; points below $S_{0}$ are pairs $(X, \underline{S})$. Observe the flatness of the locus around 7.8. Numerical values of parameters are: $\rho=0.5, \sigma^{2}-0.2, A_{0}-7.8$ and $\gamma=$ 0.5 . Units on the two axes are not the same.

Figure 6: Target zones of different widths: mean reverting, non-symetric case.

The figure is similar to Figure 5 . While the reversion point $A_{0}$ is still equal to 4.8 , the center of the exchange rate band is now at $s_{0}-9$. The free-float line and the $45^{\circ}$ Ine would intersect at 7.8 . The thin curve is an example of an exchange rate curve. The thick line is the locus of tangencies implied by the smooth pasting conditions, Observe that the locus is not flat around the central point $s_{0}-9$. 


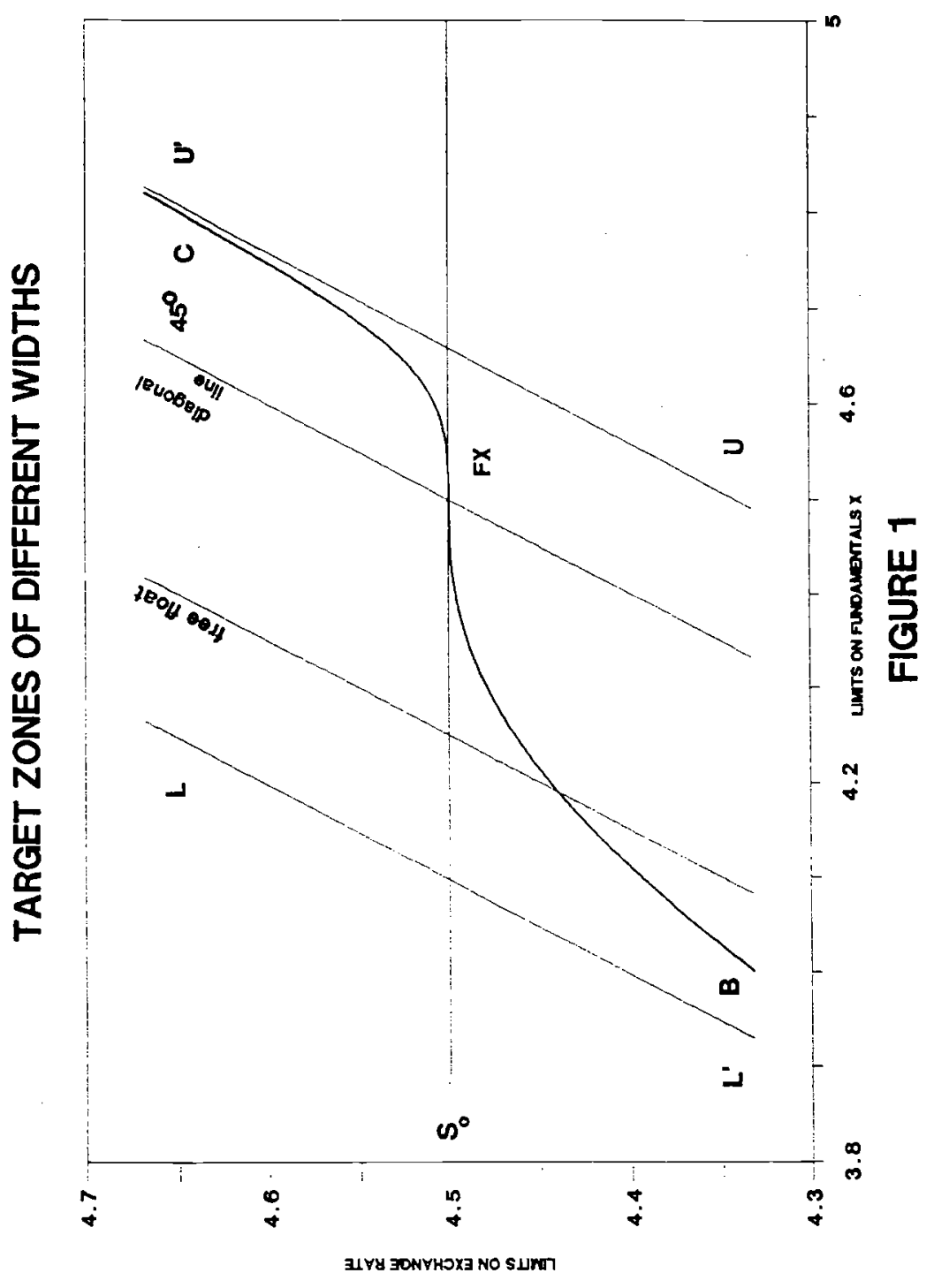




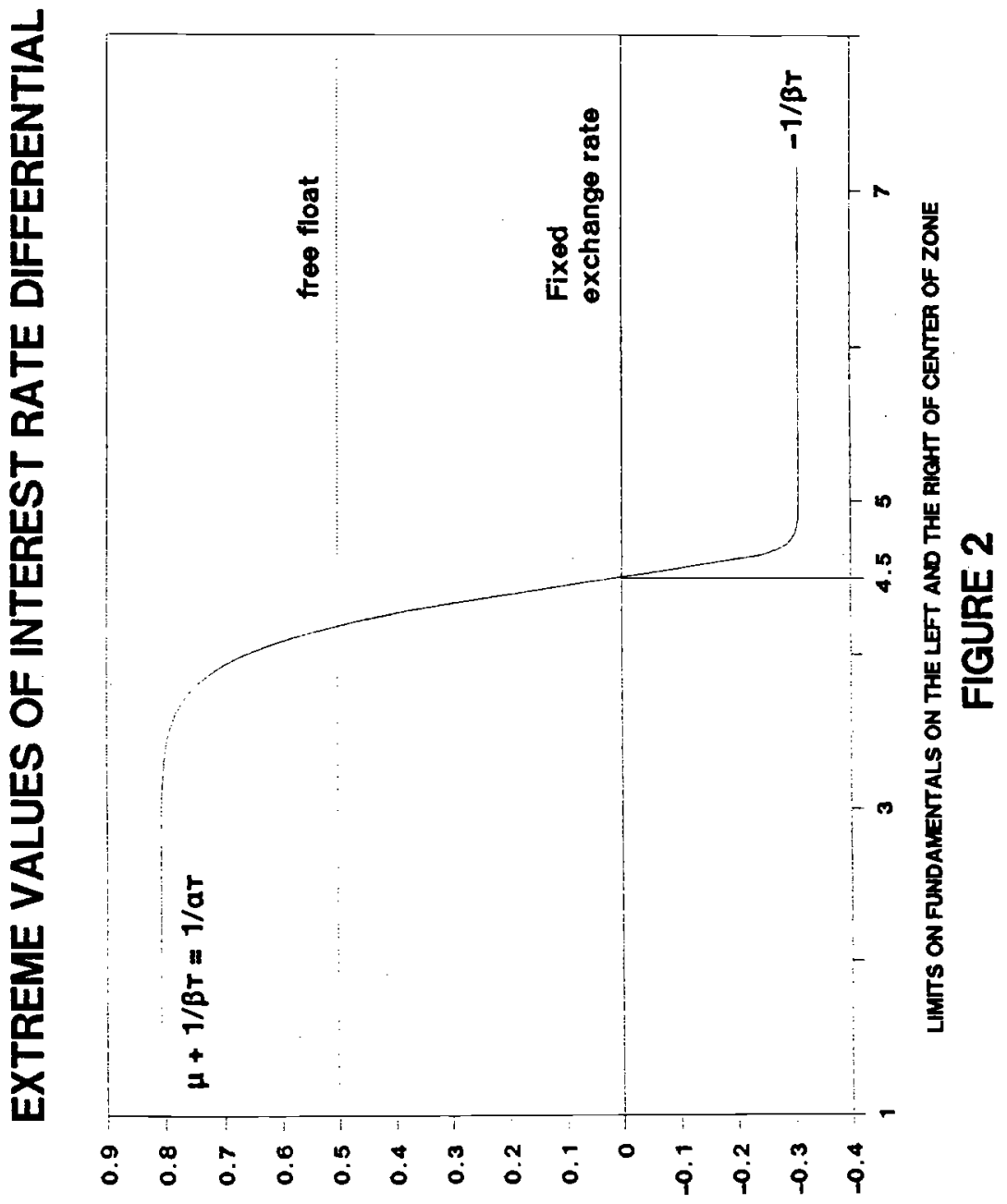

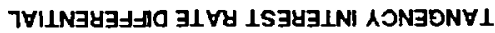




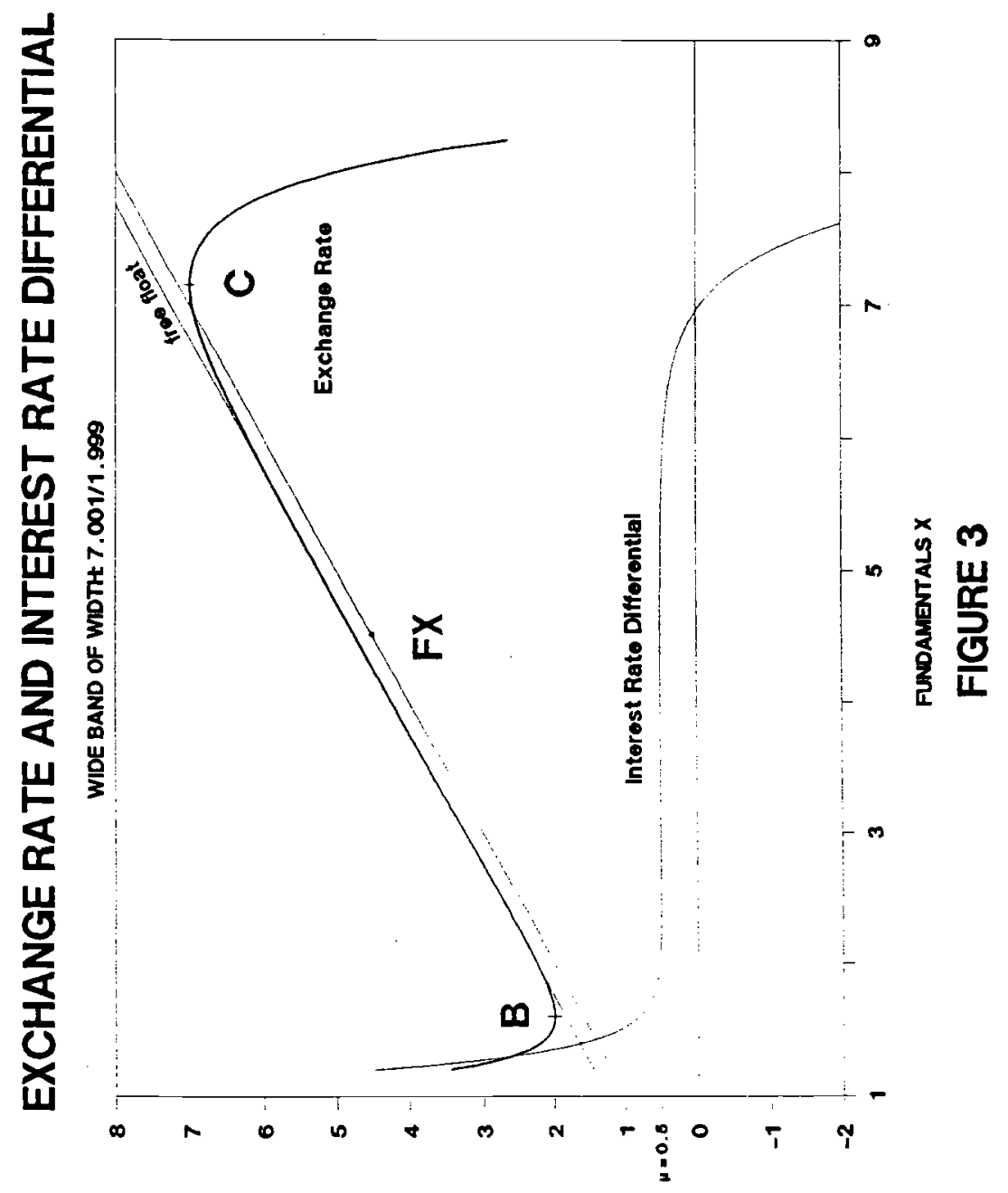

7 
INTEREST RATE DIFFERENTLAL

- 8 8 -

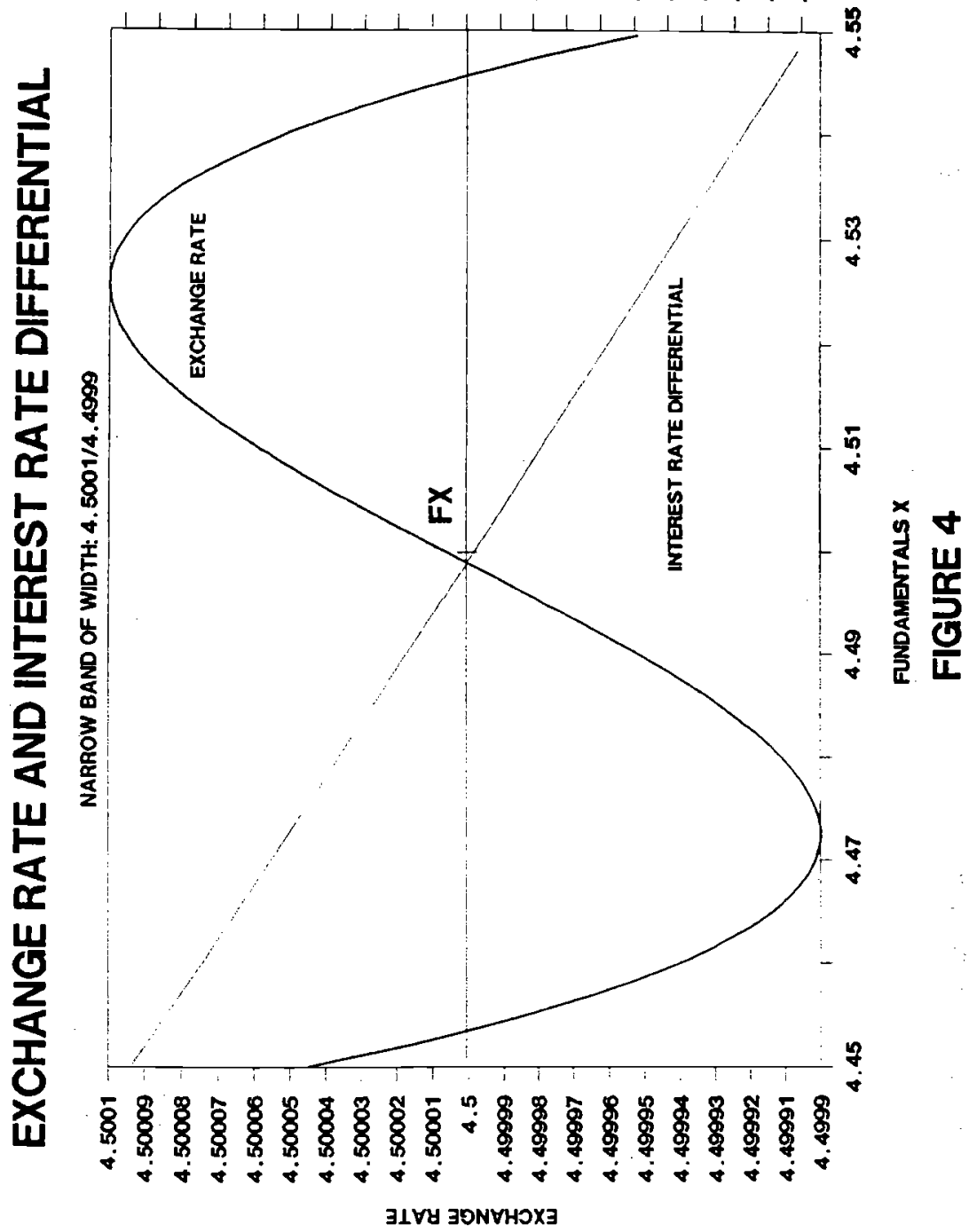




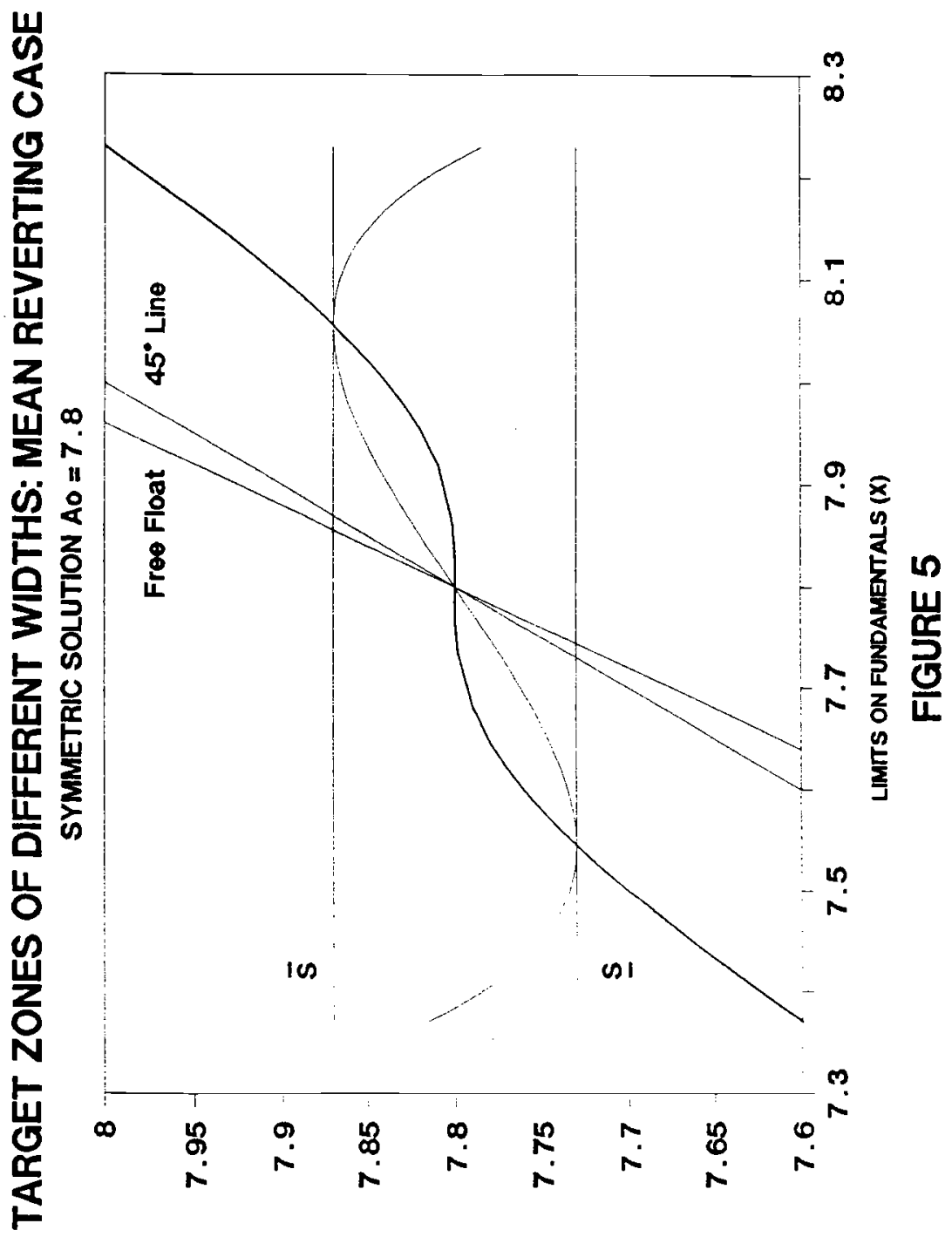




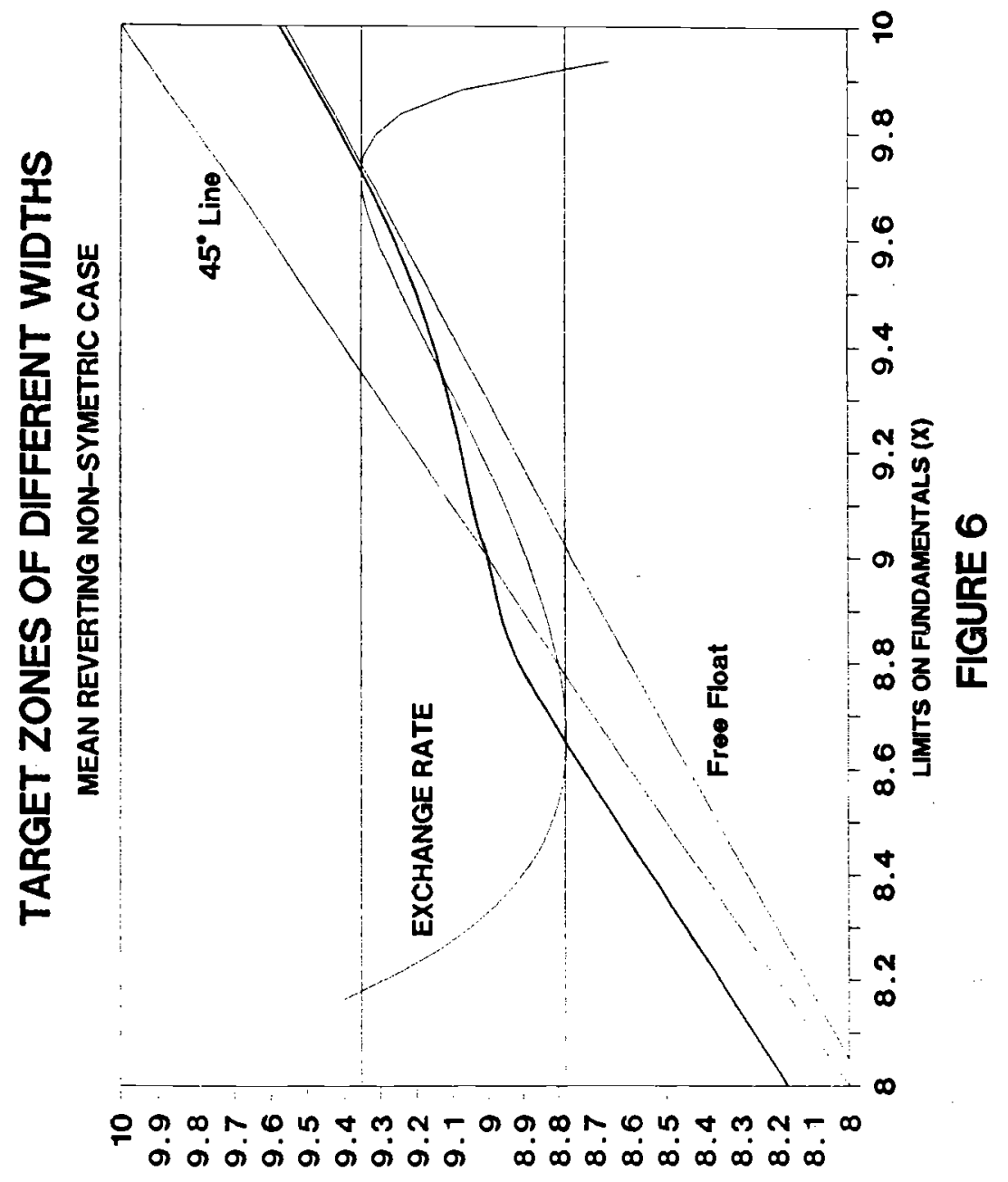

